\title{
Influence of Abiotic Factors on the Chemical Composition of Copaiba Oil (Copaifera multijuga Hayne): Soil Composition, Seasonality and Diameter at Breast Height
}

\author{
Paula C. S. Barbosa, ${ }^{a}$ Raquel S. Medeiros, ${ }^{b}$ Paulo T. B. Sampaio, ${ }^{b}$ Gil Vieira, ${ }^{b}$ \\ Larissa S. M. Wiedemann ${ }^{a}$ and Valdir F. Veiga-Junior*a \\ ${ }^{a}$ Departamento de Química, Universidade Federal do Amazonas, \\ Av. General Rodrigo Octávio, 6200, 69079-000 Manaus-AM, Brazil \\ ${ }^{b}$ Instituto Nacional de Pesquisas da Amazônia, Av. André Araújo, 2936, Aleixo, \\ 69060-001 Manaus-AM, Brazil
}

\begin{abstract}
Óleos de copaíba são importantes produtos naturais que têm sido amplamente utilizados por suas atividades cicatrizantes e anti-inflamatórias. Constituídos de sesquiterpenos e diterpenos, estes óleos apresentam composição química variável que, segundo a literatura pode ser originada por diversos fatores bióticos e abióticos. Com o objetivo de analisar a relação entre a composição química e fatores abióticos como sazonalidade, diâmetro à altura do peito $(\mathrm{DBH})$ e composição do solo, dezesseis amostras de óleo-resina de Copaifera multijuga Hayne, provenientes da Reserva Florestal Ducke (Manaus-AM, Brasil), foram analisadas por cromatografia gasosa com detector de ionização de chama (GC-FID) e acoplada à espectrometria de massas (GC-MS). Trinta e cinco substâncias foram identificadas e os resultados avaliados por técnicas de análise multivariada (análises de agrupamento hierárquico (HCA) e a análise de componentes principais (PCA)), permitindo a diferenciação das amostras em dois grupos com composições distintas. Um deles apresentou como substância majoritária $\beta$-cariofileno enquanto o outro apresentou o óxido de cariofileno, essa variação na composição parece depender do tipo de solo. Outros fatores, anteriormente descritos como essenciais para a definição da composição química dos óleos de copaíba, como sazonalidade e DBH, não mostraram influência significativa sobre a composição química dos óleos-resina desta espécie.
\end{abstract}

Copaiba oils are important medicinal products used primarily for their healing and antiinflammatory activities. Consisting of sesquiterpenes and diterpenes, these oils have variable composition which, according to the literature, may originate from several factors. In order to analyze the relationship between chemical composition and abiotic factors such as seasonality, diameter at breast height $(\mathrm{DBH})$ and soil composition, sixteen of oilresin samples of Copaifera multijuga Hayne, from the Ducke Forest Reserve (Manaus City, Amazon State, Brazil), were analyzed by gas chromatography with flame ionization detection (GC-FID) and coupled with mass spectrometry (GC-MS). Thirty-five compounds were identified and the results evaluated by multivariate analysis (hierarchical cluster analysis (HCA) and principal component analysis (PCA)), allowing differentiation of the samples into two groups with different compositions. One of them presented $\beta$-caryophyllene as the major constituent, while the other presented caryophyllene oxide. This variation in composition appears to depend on soil type. Other factors previously described as essential for defining the chemical composition of copaiba oils, such as seasonality and DBH, showed no significant influence on the chemical composition of oils of this species.

Keywords: oilresins, chemical variability, multivariate analysis, seasonal influence, diameter at breast height, soil type

*e-mail: valdirveiga@ufam.edu.br 


\section{Introduction}

The genus Copaifera belongs to the family Fabaceae, sub-family Caesalpinoideae, and comprises around 72 species, of which at least 20 occur only in Brazil. Among the most abundant species are $C$. langsdorffii Desf., C. officinalis L., C. guianensis Desf., C. reticulata Ducke, C. cearensis Huber ex Ducke and C. multijuga Hayne. ${ }^{1-3}$ The latter is found mainly in the Amazonas and Pará States. ${ }^{3,4}$ Popularly known as "copaibeiras", these trees are large and slow-growing. The copaiba oil is obtained from an incision in the trunk, which produces a viscous oilresin rich in sesquiterpenes (volatile fraction) and diterpenes (resinous fraction) known as white copaiba..$^{5-8}$

The wood of the trees is of good quality, but felling them is prohibited in some Brazilian states, like Amazonas, due to over-exploitation and wholesale extraction, with "copaibeiras" being cut and opened to obtain the oilresin. ${ }^{6.9}$ This oilresin is one of the most economically important Amazonian products, and is used in cosmetics and perfume industries as well as by traditional populations and pharmaceutical industry for its medicinal properties, as a wound-healer and anti-inflammatory. ${ }^{10-19}$ There is evidence that diterpene acids are responsible for the anti-inflammatory effect,,$^{20}$ together with sesquiterpene hydrocarbons, the latter with probable synergic effects. ${ }^{21}$

Despite its therapeutic properties, one of the greatest hindrances to the wider commercialization and application of this oilresin in the pharmaceutical and cosmetics industries is the chemical variability within and between species that these oils present, suggesting a need to establish quality control standards..$^{6-8,22-26}$ The variation in the chemical composition of oilresins of copaiba is already known and widely reported in the literature, although the factors that cause this variability are not yet known.

Established techniques, as well as more modern techniques for isolation and identification, such as high performance liquid chromatography (HPLC), chromatography with infrared detection for supercritical fluid (SFC-FT-IR) and gas chromatography coupled with mass spectrometry with chromatographic columns of chiral stationary phase (permethylated $\beta$-cyclodextrin), have led to a better knowledge of the chemical composition of these oilresins, ${ }^{6}$ with more than 100 sesquiterpenes and 40 diterpenes having been identified. ${ }^{6,8}$ This composition has been described in various articles, but despite the extensive literature on the composition of oilresins from copaiba, the chemical composition of the oilresin is only described in the literature for seventeen species of Copaifera. ${ }^{27}$

Variations in the sesquiterpene fraction of these oils are very large, with seasonal variations occurring in a species or between species. ${ }^{28}$ Some authors attribute the variability of these components to the mixture of oils of different botanical species, or specimens of different ages and growing in different places, misidentification of species, or in the case of commercial oils, problems of counterfeiting/adulteration by mixing the other types of oils of lesser value. ${ }^{4,6}$ The variation in chemical composition and production of these oils with regard to diurnal variations, ${ }^{28}$ seasonality, ${ }^{24-26,28-33}$ related to diameter at breast height $(\mathrm{DBH}),{ }^{24,29,34-36}$ and soil type $\mathrm{e}^{24,29,34,36-39}$ have been extensively reported. Although this variation seems to be more sensitive to biotic factors such as injuries caused by insects and fungi, ${ }^{40,41}$ than to light and nutrients ${ }^{42}$ it has also been reported as a possible factor influencing this variation in chemical composition. In fact, some studies have attempted to relate to the synthesis of secondary metabolites as a result of fungal attack and herbivorous insects. ${ }^{43-45}$

Another difficulty found is the lack of detail given in the literature, which often does not specify the species of Copaifera being studied, and sometimes does not even reference the botanical identification. Also, the lack of definition regarding the location and season in which the oilresin was collected, or reports on species that are not endemic to the region of study, also make standardization of the chemical composition of these oils difficult, hindering their quality control, and consequently, the quality of the products derived from them. Furthermore, the majority of studies carried out focus on the chemical characterization of the oilresin, and there have been few studies on the causes of variation in the chemical composition of this oil. Therefore, the knowledge of the factors that cause this variability in the chemical composition of copaiba oils is essential. So that, they can be used as a raw material for medicines and cosmetics since this variation can influence the pharmacological action and toxicity of these oils, and of the products that use them in their compositions, compromising their quality. $23,25,26$

The objective of this work was to carry out statistical analyses of the organic chemical composition of copaiba oils from the species Copaifera multijuga Hayne collected from a single region in the Ducke Forest Reserve of INPA (Instituto Nacional de Pesquisas da Amazônia) in Manaus City (Amazonas State, Brazil) during the dry season, from trees with variations in diameter at breast height and soil type: sandy (clay content $\leq 30 \%$ ) and clay (clay content $>60 \%$ ). The chemical composition, defined by gas chromatography with ionization flame detectors (GC-FID) and mass spectrometry (GC-MS), was studied by hierarchical cluster analysis (HCA) and principal component analysis (PCA). 


\section{Experimental}

Copaiba oils

Sixteen samples of copaiba oils from C. multijuga Hayne were collected by direct extraction, through incisions in the trunk with a manual metal auger, in November 2004 (dry season) and May 2005 (wet season) from different individuals located in the Ducke Forest Reserve (S 2 $57^{\prime} 43^{\prime \prime}$, W 59 55'38', 120 m), Manaus City (Amazonas State, Brazil). The selection criteria used were: intact trees (never collected from before), and with DBH (diameter at breast height) greater than $30 \mathrm{~cm}$. The soil type was also analyzed, i.e., sandy (clay content $\leq 30 \%$ ) or clay (clay content $\geq 60 \%$ ). The classification of soil types was based on the clay contents of the soil samples collected, which were submitted to granulometric analysis, through the decantation method. DBH and clay contents for each tree are shown in Table 1.

The perforation was made in the trunk at a height of approximately $1 \mathrm{~m}$ from the soil, and the oilresin was collected until exhaustion, which prevents the ability to

Table 1. Chemical composition of Copaifera multijuga oilresins, DBH and clay content

\begin{tabular}{|c|c|c|c|c|c|c|c|c|c|c|c|c|c|c|c|c|c|}
\hline \multicolumn{2}{|l|}{ Tree ID code } & \multicolumn{2}{|c|}{ M09 } & \multicolumn{2}{|c|}{ M10 } & \multicolumn{2}{|c|}{ M14 } & \multicolumn{2}{|c|}{ M21 } & \multicolumn{2}{|c|}{ M27 } & \multicolumn{2}{|c|}{ M31 } & \multicolumn{2}{|c|}{ M36 } & \multicolumn{2}{|c|}{ M43 } \\
\hline \multirow{2}{*}{\multicolumn{2}{|c|}{$\begin{array}{l}\mathrm{DBH} / \mathrm{cm} \\
\text { Clay content / \% }\end{array}$}} & \multicolumn{2}{|c|}{34.7} & \multicolumn{2}{|c|}{47.3} & \multicolumn{2}{|c|}{38.8} & \multicolumn{2}{|c|}{46.3} & \multicolumn{2}{|c|}{32.0} & \multicolumn{2}{|c|}{41.8} & \multicolumn{2}{|c|}{42.6} & \multicolumn{2}{|c|}{50.8} \\
\hline & & 82 & 65 & 85. & .84 & 77. & & 77 & 83 & 68. & .00 & 19. & 66 & 26 & 91 & 2.3 & 34 \\
\hline Constituent & RI & $\mathrm{C} 1$ & $\mathrm{C} 2$ & $\mathrm{C} 1$ & $\mathrm{C} 2$ & $\mathrm{C} 1$ & $\mathrm{C} 2$ & $\mathrm{C} 1$ & $\mathrm{C} 2$ & $\mathrm{C} 1$ & $\mathrm{C} 2$ & $\mathrm{C} 1$ & $\mathrm{C} 2$ & $\mathrm{C} 1$ & $\mathrm{C} 2$ & $\mathrm{C} 1$ & $\mathrm{C} 2$ \\
\hline$\delta$-Elemene & 1335 & - & - & - & - & - & - & 0.88 & - & - & - & - & - & - & - & 1.56 & 1.25 \\
\hline$\alpha$-Cubebene & 1345 & 0.75 & 0.87 & 0.99 & 0.97 & 0.96 & 0.93 & - & 0.68 & 0.73 & 0.82 & 0.56 & - & 0.22 & - & - & - \\
\hline$\alpha$-Ylangene & 1373 & - & - & - & - & - & - & - & 0.10 & 0.10 & - & 0.28 & - & 0.35 & - & - & - \\
\hline$\alpha$-Copaene & 1374 & 12.67 & 15.04 & 14.87 & 14.11 & 11.17 & 11.38 & 7.16 & 5.65 & 6.24 & 11.11 & 6.47 & 6.68 & 2.03 & 2.00 & 6.04 & 5.51 \\
\hline$\beta$-Elemene & 1389 & - & - & - & - & - & - & 8.56 & 1.15 & 1.28 & - & - & - & 0.70 & 0.67 & 5.31 & 6.10 \\
\hline$\alpha$-Gurjunene & 1409 & - & - & 0.22 & 0.20 & 0.37 & - & - & 0.18 & 0.19 & 0.13 & - & - & 0.18 & 0.18 & - & - \\
\hline$\beta$-Caryophyllene & 1417 & 13.14 & 34.99 & 55.46 & 50.41 & 61.53 & 64.04 & 5.08 & 29.82 & 32.41 & 52.66 & 47.48 & 20.79 & 60.10 & 60.58 & 16.00 & 7.58 \\
\hline trans $-\alpha$-Bergamotene & 1432 & - & - & - & - & 0.55 & 0.59 & - & 0.22 & 0.22 & 7.51 & - & - & 7.10 & 6.17 & 20.93 & 19.77 \\
\hline$\gamma$-Elemene & 1434 & - & - & - & - & - & - & 1.40 & - & - & - & - & - & - & - & - & - \\
\hline$\alpha$-Humulene & 1452 & 2.73 & 5.29 & 7.74 & 7.05 & 8.25 & 8.56 & 1.37 & 4.27 & 4.56 & - & 6.80 & 4.00 & 8.70 & 8.89 & 3.09 & 1.99 \\
\hline allo-Aromadendrene & 1458 & 0.87 & 1.03 & 1.00 & - & - & - & - & - & - & - & - & - & - & - & - & - \\
\hline$\alpha$-Curcumene & 1479 & - & - & - & - & - & - & - & - & - & 0.23 & - & - & 0.78 & 1.10 & 0.61 & 0.62 \\
\hline$\alpha$-Amorphene & 1483 & 2.34 & 2.52 & 2.52 & 2.51 & 1.47 & 1.56 & 2.29 & 4.48 & 4.61 & 1.72 & 3.62 & 4.05 & 1.30 & 1.39 & 0.90 & 1.01 \\
\hline Germacrene D & 1484 & - & 3.12 & 1.72 & 1.58 & 1.30 & 1.45 & - & 15.86 & 16.65 & 2.21 & 13.13 & - & - & 1.13 & - & - \\
\hline$\beta$-selinene & 1489 & - & - & - & - & - & - & - & 0.20 & 0.16 & - & - & - & - & - & - & 0.31 \\
\hline$\alpha$-Muurolene & 1500 & 0.77 & 1.00 & 1.35 & 1.29 & 0.81 & 0.81 & 1.50 & 3.17 & 3.30 & 0.89 & 2.60 & 0.77 & 0.43 & 0.44 & 0.59 & 0.85 \\
\hline Biciclogermacrene & 1500 & - & - & - & - & - & - & - & - & - & - & - & - & - & - & - & - \\
\hline$\gamma$-Cadinene & 1513 & 0.61 & - & 0.14 & 0.14 & 0.22 & 0.16 & - & 1.57 & 1.69 & 0.37 & - & 0.89 & - & - & 0.51 & - \\
\hline$\delta$-Cadinene & 1522 & - & 1.69 & 3.71 & 3.56 & 2.57 & 2.59 & - & 5.01 & 5.39 & 2.77 & 2.26 & - & 0.68 & 0.82 & 0.72 & - \\
\hline trans-Cadina-1,4-diene & 1533 & - & - & - & - & - & - & - & 0.16 & - & - & - & - & - & - & - & - \\
\hline Selina-3,7-(11)-diene & 1545 & - & - & 0.29 & - & - & - & - & - & - & - & - & - & - & - & - & - \\
\hline Germacrene B & 1559 & - & - & - & - & - & - & - & - & - & - & - & - & - & - & 2.84 & 0.52 \\
\hline Palustrol & 1567 & - & - & 0.38 & - & - & - & - & - & - & - & - & - & - & - & - & - \\
\hline Spathulenol & 1577 & 1.19 & 1.19 & - & - & - & - & - & - & - & - & 0.81 & 2.09 & - & - & - & - \\
\hline Caryophyllene oxide & 1582 & 31.52 & 10.01 & 0.33 & 0.93 & 0.41 & 0.20 & 36.43 & 0.28 & 0.60 & 0.54 & 0.57 & 29.15 & 1.28 & 0.38 & 11.72 & 19.91 \\
\hline Globulol & 1590 & - & 0.12 & - & 0.10 & - & - & - & 0.22 & 0.22 & - & - & - & - & - & - & - \\
\hline Viridiflorol & 1592 & - & - & - & 0.41 & - & - & - & 0.38 & 0.41 & - & - & - & - & - & - & - \\
\hline Rosifoliol & 1600 & - & - & - & - & - & - & - & 0.12 & - & - & - & - & - & - & - & - \\
\hline Ledol & 1602 & - & 1.70 & 0.29 & 0.39 & - & - & - & 0.21 & 0.36 & 0.19 & 0.7 & 4.26 & 0.24 & 0.21 & 1.92 & 3.48 \\
\hline Torreyol & 1644 & 1.51 & 1.58 & 1.93 & 1.93 & 0.48 & 0.28 & - & 1.61 & 1.57 & - & 1.63 & 2.42 & - & 0.70 & 0.70 & 1.33 \\
\hline$\alpha$-Cadinol & 1652 & 1.46 & 1.45 & 0.52 & 0.50 & 0.29 & - & 2.27 & 2.10 & 2.29 & 0.18 & 0.72 & 0.96 & - & 0.16 & 1.64 & 1.59 \\
\hline Copalic acid & & 3.10 & 3.42 & 2.78 & 5.66 & 5.17 & 4.30 & 1.66 & 7.09 & 4.28 & 2.89 & 2.52 & 4.87 & 3.31 & 2.46 & 2.92 & 2.48 \\
\hline 3ß-Hydroxy-copalic acid & & 0.18 & 0.51 & 0.17 & 1.07 & - & - & - & 0.97 & 0.31 & 0.24 & 0.41 & 1.44 & 0.52 & 0.29 & 2.16 & 1.15 \\
\hline 3ß-Acetoxy-copalic acid & & - & 0.51 & 0.22 & 0.70 & - & - & - & 0.95 & 0.55 & 0.37 & 0.18 & - & 0.32 & 0.20 & 0.30 & 0.26 \\
\hline Pinifolic acid & & 3.31 & 3.16 & 1.29 & 2.47 & 1.81 & 1.31 & 3.04 & 4.22 & 2.55 & 2.04 & 1.48 & 2.92 & 1.45 & 1.03 & 1.50 & 0.77 \\
\hline Total & & 76.15 & 89.20 & 97.92 & 95.98 & 97.36 & 98.16 & 71.64 & 90.67 & 90.67 & 86.87 & 92.22 & 85.29 & 89.69 & 88.80 & 81.96 & 76.48 \\
\hline
\end{tabular}

C1: samples collected during the dry season (November 2004); C2: samples collected during the rainy season (May 2005). 
replicate. At the moment of collection, the oilresins were collected in plastic flasks and covered with aluminum foil to prevent oxidation caused by light. The oils were then transferred to amber flasks and stored in a refrigerator, and a small aliquot was separated for subsequent analyses. The oilresins were esterified as soon as they arrived at the laboratory, but were only analyzed in 2007.

\section{Chromatographic analysis of copaiba oils}

The copaiba oils were esterified with diazomethane in ether solution and diluted with dichloromethane. The solutions obtained were analyzed by gas chromatography with a flame ionization detector (GC-FID) for quantitative analysis and determination of retention rates, and by gas chromatography coupled with mass spectrometer (GC-MS) to obtain the mass spectra. The oilresins were analyzed by a Varian ${ }^{\oplus}$ CP 3800 model (Palo Alto, USA) gas chromatograph with flame ionization detector (FID). The analyses were performed with column CP-Sil 5 CB (100\% dimethylpolysiloxane) $\operatorname{Varian}^{\oplus}$; a measurement of $15.0 \mathrm{~m} \times 0.25 \mathrm{~mm}$ i.d., $0.25 \mu \mathrm{m}$ was used as carrier gas, helium flow of $2.0 \mathrm{~mL} \mathrm{~min}{ }^{-1}$. The injection mode was split 1:10 with the gun held at $270{ }^{\circ} \mathrm{C}$. The detector temperature was $300{ }^{\circ} \mathrm{C}$ and the oven was programmed from 120 to $150{ }^{\circ} \mathrm{C}$ to $3{ }^{\circ} \mathrm{C} \mathrm{min}{ }^{-1}$ and 150 to $280{ }^{\circ} \mathrm{C}$ to $8{ }^{\circ} \mathrm{C} \mathrm{min}^{-1}$, followed by isotherm $280{ }^{\circ} \mathrm{C}$ for $5 \mathrm{~min}$. A homologous series of linear hydrocarbons was co-injected for the determination of retention rates. After analysis by GC-FID, oilresins were analyzed by a gas chromatograph model Shimadzu $^{\odot}$ QP-2010 (Kyoto, Japan) detector by mass spectrometry (GC-MS). The analyses were performed with Varian ${ }^{\oplus}$ VF-1MS column measuring $15.0 \mathrm{~m} \times 0.25 \mathrm{~mm}$ i.d., $0.25 \mu \mathrm{m}$. The analytical conditions were the same as those used for GC-FID, and the detection technique used was electron impact at $70 \mathrm{eV}$.

\section{Identification of the constituents of copaiba oilresins}

The chemical composition of copaiba oils was performed using the retention time data obtained by GC-FID and mass spectra obtained by GC-MS. The retention rates were calculated using the van der Dool-Kratz equation, linking the retention times of substances present in the copaiba with the retention times of standard linear hydrocarbons (homologous series of $\mathrm{C}_{9}-\mathrm{C}_{22}$ ) and $\beta$-caryophyllene (SigmaAldrich (St. Louis, USA) $\geq 98.5 \%$ purity). These were coinjected with the samples, which were analyzed in sequence. As all the constituents detected were already known, the retention indices, mass spectra and fragmentation patterns are well-defined in the literature. The results obtained were compared with data from the Wiley 7.0 Spectrotech supplied by Shimadzu ${ }^{\circ}$, with the standard data for the diterpenes previously isolated in the literature. ${ }^{46}$

\section{Statistical analysis}

The contents of constituents identified (chromatographic results) in the samples of oilresin of copaiba, DBHs and the clay contents (soil type) constitute a multivariate data set that was interpreted by HCA and PCA. Preprocessing of the data was carried out by normalization by logarithm, with the aim of reducing the influence of undesirable variations in the data set. With the values obtained, a data matrix was created ( 16 lines $\times 37$ columns): 16 lines corresponded to the samples, 35 columns corresponded to the values of the constituents identified in the samples, 1 column corresponded to the DBHs and 1 column corresponded to the clay contents (which classify the soil types).

HCA was performed using the matrices of 16 samples and the 37 variables (constituents identified, DBHs and clay contents). Similarity was calculated based on the Euclidean distance, using the Ward method. HCA was carried out in order to determine similarities in chemical composition between different samples from trees with different DBHs and different soil types, collected in the dry and rainy seasons.

PCA was carried out with 5 selected variables, namely: $\beta$-caryophyllene, caryophyllene oxide, copalic acid, pinifolic acid and clay content. The matrix arrangement consisted of 16 lines (samples) and 5 columns (selected variables). PCA showed the sample distribution and the importance of the variables. ${ }^{47-49}$

All the mathematical and statistical operations were carried out using the free software R. 2.14.0 ${ }^{\circledR}$.

\section{Results and Discussion}

The copaiba oils were collected from eight matrices, half in the dry season (November 2004) and half in the wet season (May 2005), in a region subject to the same biological environment and rainfall. The trees presented different DBH, and were located in sandy soils (3 trees) and clay soils (5 trees).

The composition, relative quantification and respective retention indices (RI) for the chemical constituents of the oilresin of C. multijuga Hayne are presented in Table 1, as well as the DBH data and clay contents for each tree. Thirty-five constituents were identified, estimated to represent between 71.64 and $97.92 \%$ of the total oilresin content. The compounds $\alpha$-copaene, $\alpha$-humulene, 
$\alpha$-amorphene, $\beta$-caryophyllene, caryophyllene oxide, copalic acid and pinifolic acid were detected in all the cases analyzed. The compound $\alpha$-humulene was detected in fifteen samples.

The $\beta$-caryophyllene, considered a chemical marker of the sesquiterpene fraction of copaiba oils, ${ }^{25,50}$ was the major constituent in eleven of the sixteen samples analyzed. Of these eleven samples, five were collected in each dry season (three from trees located in clay soils (M10-C1, M14-C1 and M27-C1) and two from trees located in sandy soils (M31-C1 and M36-C1)) and six were collected in the rainy season (five from trees located in clay soils (M09-C2, M10-C2, M14-C2, M21-C2 and $\mathrm{M} 27-\mathrm{C} 2$ ) and just one from trees growing in sandy soil (M36-C2)). $\beta$-caryophyllene has already been described as the major constituent of other authentic oilresins of C. multijuga,${ }^{11,26,51,52}$ C. langsdorffii, ${ }^{53}$ C. cearensis, ${ }^{11}$ C. reticulata, ${ }^{11,38,54-56}$ C. duckei, ${ }^{33}$ C. pubiflora ${ }^{57}$ and also in essential oils of leaves of $C$. trapezifolia. ${ }^{58}$

$\beta$-caryophyllene is present in many other plants. It is used as fragrances in perfumes and other cosmetics due to its odor, which is described as woody and sharp. ${ }^{59} \mathrm{It}$ is also described as a volatile compound given off by plants into the atmosphere in response to attack by herbivores or changes in abiotic factors. ${ }^{60}$ Multiple biological activities are attributed to $\beta$-caryophyllene, such as insecticidal, ${ }^{61,62}$ antifungal, ${ }^{63,64}$ local anesthetic, ${ }^{65}$ anticarcinogenic ${ }^{66-71}$ and anti-inflammatory. ${ }^{72-74}$ This sesquiterpene presents a cyclobutane ring, rare in nature, being commonly found in a mixture with iso-caryophyllene and $\alpha$-humulene. ${ }^{75}$ Because it is an unsaturated hydrocarbon, it is susceptible to oxidation when exposed to air, forming caryophyllene oxide. ${ }^{58}$ The caryophyllene oxide has previously been described as a repellant, ${ }^{61}$ antitermitic and antifungal ${ }^{63}$ Its antimicrobial, ${ }^{64}$ analgesic and anti-inflammatory activities have also been reported. ${ }^{73,74}$

Caryophyllene oxide was found to be the major constituent in four samples, from which two samples collected in the dry season were from trees located in clay soils (M09-C1 and M21-C1) and the other two were collected in the rainy season, from trees located in sandy soils (M31-C2 and M43-C2). Caryophyllene oxide had been reported as a major constituent in other authentic oilresins of C. multijuga, and C. guianensis, ${ }^{26}$ and also for essential oils of the skins of fruits, skins of roots, stem bark and root bark of $C$. langsdorffii. ${ }^{53}$ After identifying caryophyllene oxide as the major constituent in an authentic recently extracted oilresin of $C$. guianensis, Cascon and Gilber ${ }^{26}$ believe that this sesquiterpene may be a natural product of the oilresin of copaiba, and not an artifact from oxidation due to storage.
Trans- $\alpha$-bergamotene, detected in only nine of the sixteen samples analyzed, was the major constituent of a single sample, collected in the dry season from a tree growing in sandy soil (M43-C1). Trans- $\alpha$-bergamotene has previously been reported as the major constituent of authentic oilresin of $C$. reticulata. ${ }^{55}$

Germacrene D is an important precursor of other sesquiterpenes such as cadinenes and muurolenes. ${ }^{76}$ It has already been reported as the major constituent in the sample of $C$. multijuga collected in the dry season. In the present work, germacrene D was detected in ten samples, two of them from trees growing in sandy soils and eight from trees located in clay soils, four collected in the dry season and six collected in the rainy season. Generally, germacrene D occurs together with $\delta$-cadinene, ${ }^{76}$ a fact that was also observed in this work: of the ten samples that present germacrene $\mathrm{D}$, all of them also contain $\delta$-cadinene, four samples did not present any of these two constituents, and only two contained $\delta$-cadinene without the presence of germacrene D.

The sesquiterpene $\alpha$-copaene was not the major constituent in any sample, but was identified in all of them, being the second or third constituent in eleven of the sixteen samples analyzed. This substance is commonly reported as one of the main constituents of copaiba oils, independent of the species, and has been reported as the major constituent in oilresins of $C$. paupera,${ }^{57}$ C. piresii ${ }^{57}$ and $C$. martii. ${ }^{54}$ It has also been reported as a major constituent of essential oils obtained by hydrodistillation from oilresin of $C$. martii. ${ }^{77}$

$\beta$-bisabolene has been reported as the major constituent in samples of oilresins obtained from $C$. duckei $i^{26,33,54,78}$ and C. reticulata, ${ }^{38,55}$ but not in C. multijuga. It was not detected in any of the samples from C. multijuga analyzed in this work.

Of the diterpenes identified, copalic acid, which has antimicrobial activity and has been described as a biological marker of copaiba oils,,$^{25,79-81}$ was the major diterpenic constituent in fourteen samples (M09-C2, M10-C1, M10-C2, M14-C1, M14-C2, M21-C2, M27-C1, M27-C2, M31-C1, M31-C2, M36-C1, M36-C2, M43-C1 and M43-C2). Pinifolic acid was the major diterpenic constituent in two other samples (M09-C1 and M21-C1). The $3 \beta$-hydroxy-copalic acid and $3 \beta$-acetoxy-copalic acid, both with antimicrobial activities already described, ${ }^{81}$ were detected in thirteen and eleven samples, respectively.

The results obtained by chromatographic analysis were submitted to HCA and PCA methods for the classification of sixteen samples. HCA was used to determine the similarities between the samples, based on DBH, clay content and amount of each compound detected by GC-FID and GC-MS. The results of HCA were represented 
in the form of a bidimensional chart, known as a dendogram (Figure 1), through which the clustering between samples in two distinct clusters (groups) can be seen, classifying the 16 samples.

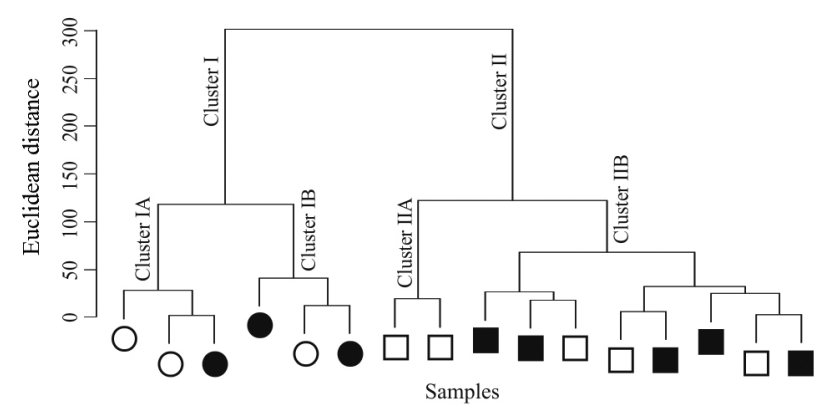

Figure 1. Dendrogram corresponding to the classification of the oleoresins of copaiba (C. multijuga). Cluster I: sandy soil samples (circle symbols) and cluster II: clay soil samples (square symbols), samples collected during the dry season (unshaded symbols) and rainy season (shaded symbols).

Cluster I was divided into two sub-clusters. Cluster IA includes three samples: two collected in the dry season (M31-C1 and M36-C1) and one in the rainy season (M36-C2), which present $\beta$-caryophyllene as the principal component, with contents ranging from 47.48 to $60.58 \%$. Cluster IB also includes three samples: one collected in the dry season (M43-C1) in which trans- $\alpha$-bergamotene was the major constituent $(20.93 \%)$ and two collected in the rainy season (M31-C2 and M43-C2), in which caryophyllene oxide was the major constituent, with contents ranging from 19.91 to $29.15 \%$.

Cluster II was subdivided into two sub-clusters, IIA and IIB. Cluster IA includes two samples: two collected in the dry period (M09-C1 and M21-C1), presenting caryophyllene oxide as the principal component, with a contents ranging from 31.52 to $36.43 \%$. Cluster IIB includes eight samples: three collected in the dry season (M10-C2, M14-C1 and M27-C1) and five collected in the rainy season (M09-C2, M10-C2, M14-C2, M21-C2 and $\mathrm{M} 27-\mathrm{C} 2)$, presenting $\beta$-caryophyllene as the principal component, with a content ranging from 29.82 to $64.04 \%$. It is observed that Clusters I and II correspond to the trees growing in sandy or clay soils, respectively, which reveal different chemical profiles of organic composition (Figures 2 and 3).

It is common for $\beta$-caryophyllene and/or its oxide to be identified as the major constituents of oilresin of copaiba, particularly in C. multijuga. However, it is widely believed that caryophyllene oxide is merely a product of the oxidation of $\beta$-caryophyllene due to inadequate storage. Cascon and Gilbert ${ }^{26}$ report that caryophyllene oxide can be found naturally in these oils. Although monitoring of $\beta$-caryophyllene oxidation by $\mathrm{H}^{1}$ nuclear magnetic resonance (NMR) has shown that the complete oxidation of this sesquiterpene in its oxide occurs in up to 15 days when exposed to light, ${ }^{53}$ the samples analyzed in this work, which were stored for a prolonged time in a refrigerator, do not appear to have suffered significant oxidation. Otherwise, the contents of oxygenated sesquiterpenes would have significantly increased in all the samples analyzed, which was not observed.

Although sesquiterpenes and diterpenes occurred in similar proportion in all the oils, different qualitative profiles were observed, as already reported in the literature, as described throughout the text. In general, the samples of cluster I (Figure 2) from the trees growing in sandy soils present greater qualitative variation and more complex chromatographic profiles when compared with the samples of cluster II (Figure 3 ) from trees growing in clay soils.

The amount of sesquiterpenes detected ranged from eighteen to forty-one in the samples collected from trees

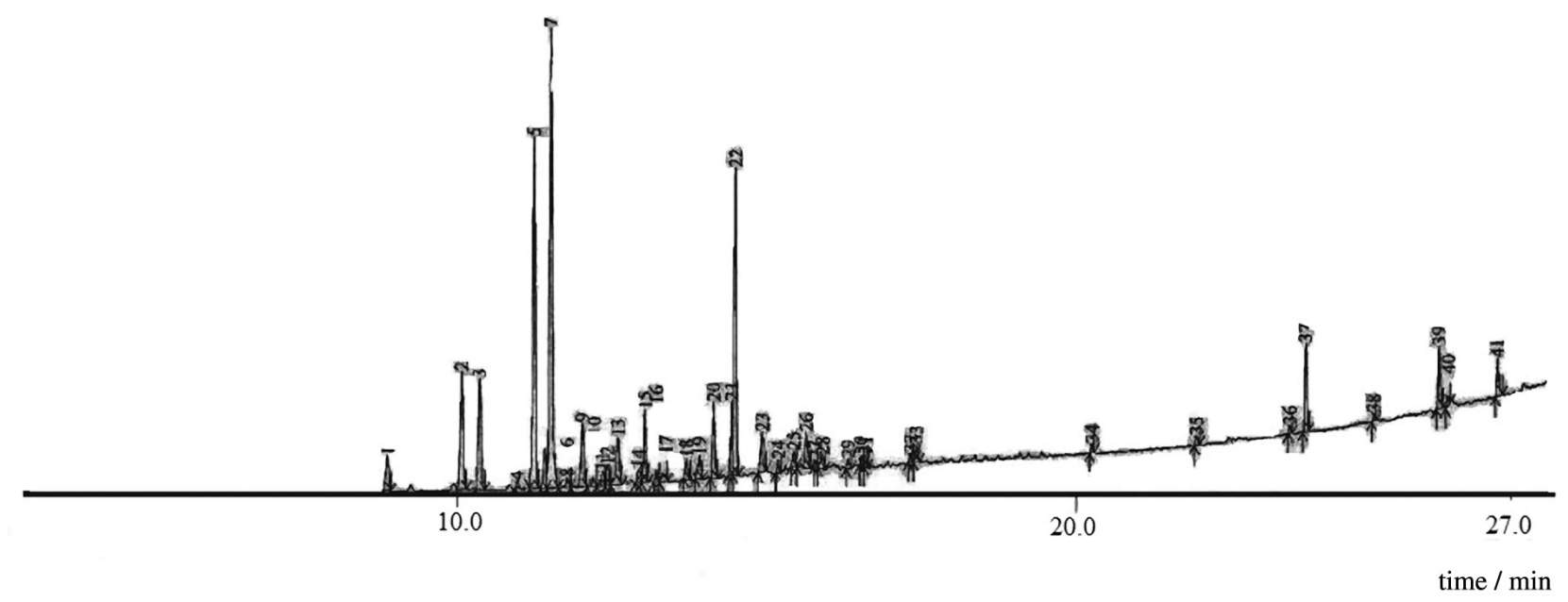

Figure 2. Chromatographic profile of the samples of cluster I, located in sandy soils. 


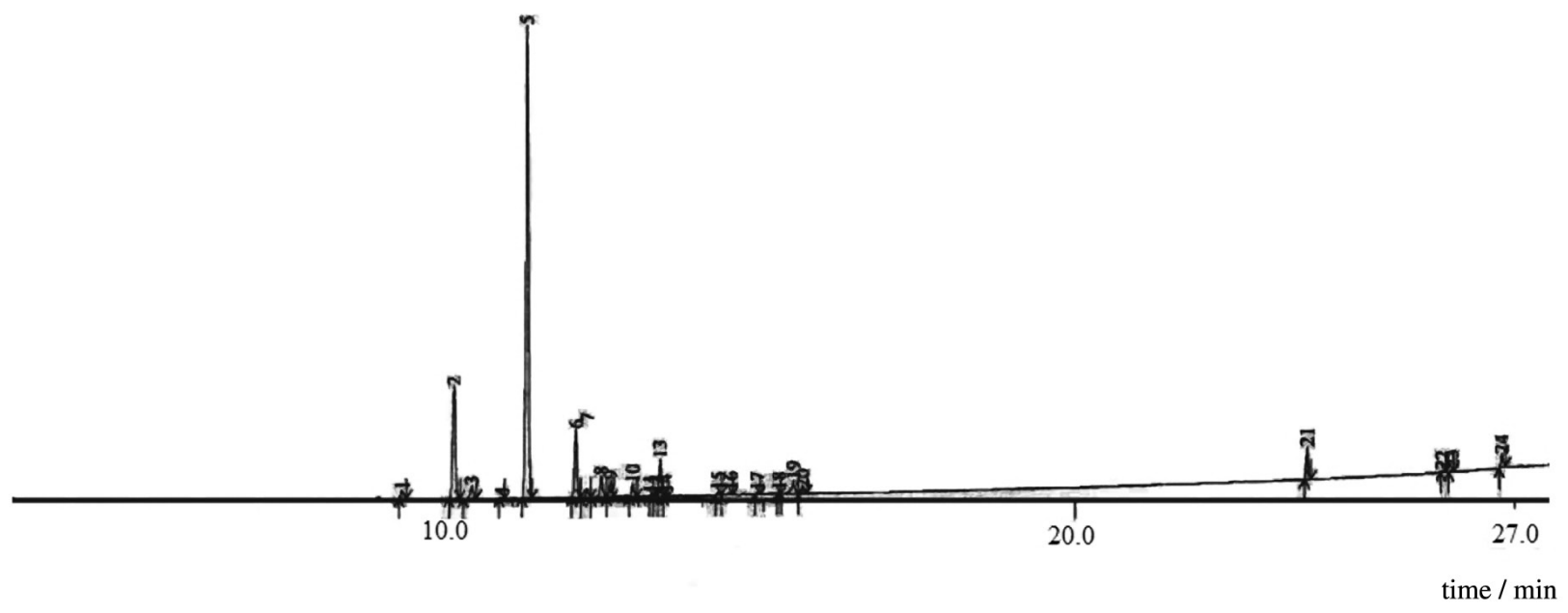

Figure 3. Chromatographic profile of samples of cluster II, located on clay soils.

located in sandy soils and from fourteen to thirty-seven in the samples collected from trees located in clay soils. As for the diterpene fraction, the number of diterpenes detected was between four and eight for samples collected from trees located in sandy soils, and between two and five for samples collected from trees located in clay soils.

According to Janzen, ${ }^{82}$ sandy soils, which are poor in nutrients, provide a higher production of secondary metabolites compared with clay soils, which are richer in nutrients. Therefore, the data analysis suggests a possible influence of soil composition on the chemical composition of these oils. Studies carried out in the Amazonas State, with authentic oilresins of $C$. multijuga, show that there is a dependence between soil texture (sandy or clay) and productivity of the oilresin, with production being higher in clay soils than in sandy soils. ${ }^{34}$ However, it was not observed any relationship between production and soil type, but it was observed that the fractions of non-oxygenated sesquiterpenes and diterpene acids are slightly higher in clay soils, while the fraction of oxygenated sesquiterpenes was higher in sandy soils. ${ }^{29}$

However, results that contradict this theory were observed in samples of $C$. reticulata, which present higher concentrations of trans- $\alpha$-bergamotene in samples from trees growing in sandy soils. Therefore, it is possible that the biosynthesis of certain compounds is affected by the availability of nutrients, contradicting the hypothesis of Janzen. ${ }^{38,82}$ Studies carried out with leaves of adult trees of C. multijuga did not show any significant differences in the production of sesquiterpene compounds in relation to soil type. ${ }^{39}$

Although a qualitative variation has been observed between samples, the sesquiterpene fraction was between 84.83 and $95.54 \%$ of the composition of these oils, as already reported for oilresins of this species. ${ }^{26}$ In previously published papers, Veiga-Junior et al. ${ }^{11}$ found $85.5 \%$ of sesquiterpenes in oilresins of the same species, suggesting that there is no relationship between rainfall and chemical composition of these oilresins.

It should be highlighted that important variations in the contents of the main components were found, particularly in $\beta$-caryophyllene, which had the highest percentage in a copaiba oil (5.08-64.04\%) collected from a tree growing in clay soil, in the wet season, caryophyllene oxide, which had the highest percentage in a copaiba oil (0.20-36.43\%) collected from a tree growing in clay soil, collected in the dry season, and trans- $\alpha$-bergamotene, which had the highest percentage in a copaiba oil (0.22-20.93\%) collected from a tree growing in sandy soil, collected in the dry season.

In PCA, the data were projected through linear combinations of the original variables $\beta$-caryophyllene, caryophyllene oxide, copalic acid and pinifolic acid, as they were identified in all samples as being the major constituents, and clay content, as this variable proved to be important in HCA. The graphs were then obtained for scores and loading, i.e., the distribution of samples according to the importance of the variables.

Figures $4 \mathrm{a}$ and $4 \mathrm{~b}$ show the graphs of the scores and loadings, respectively, both of dimension 1 (Dim 1) with $42.38 \%$ of variance versus dimension 2 (Dim 2) with $38.10 \%$ variance, representing $80.48 \%$ of the total information. In these figures, it can be seen that Dim 1 separates the oils with higher caryophyllene oxide contents into positive scores, while Dim 2 separates the oils from trees located in sandy soils into negative scores, and the oils from trees located in clay soils, into positive scores.

The oils with higher caryophyllene oxide contents are more to the left of the score graph (Figure 4a), while the 
(a)

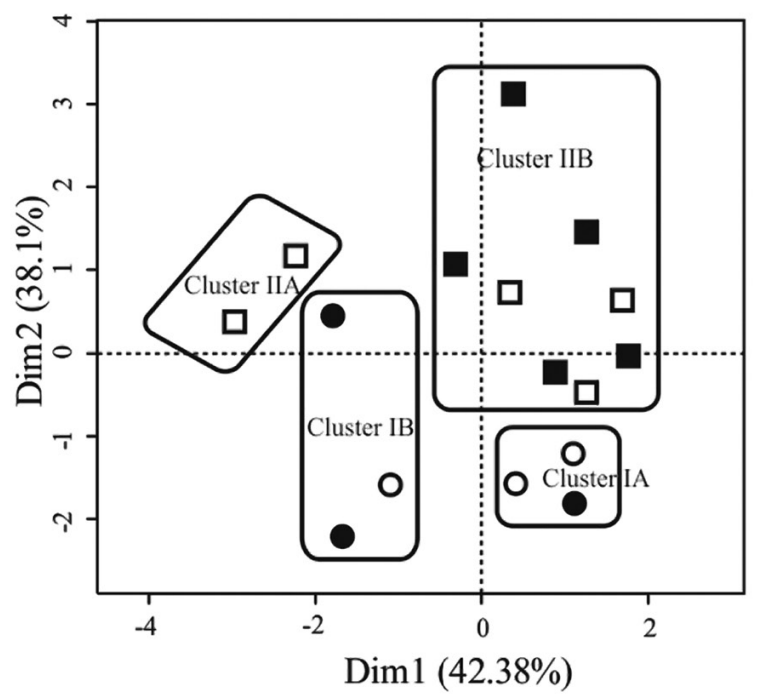

(b)

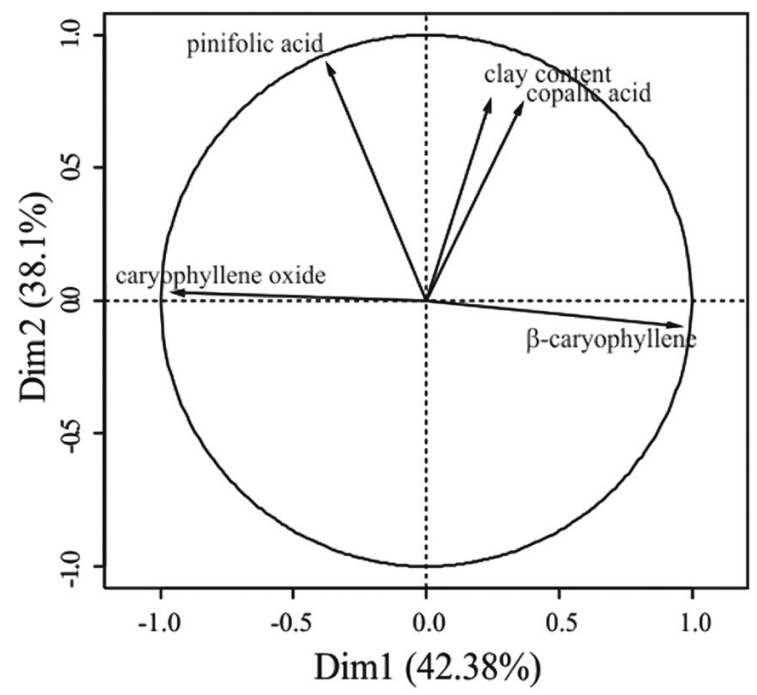

Figure 4. Graphs of (a) scores and (b) loadings for Dim 1 vs. Dim 2, corresponding to the classification of copaiba oilresins (C. multijuga): sandy soil samples (circle symbols) and clay soil samples (square symbols), samples collected during the dry season (unshaded symbols) and rainy season (shaded symbols).

oils with higher $\beta$-caryophyllene contents are more to the right, suggesting, once again, a possible influence of the soil type, with the trees developing according to the chemical composition of these oils.

Thus, four main types of oilresin were found, according to the chemical composition and soil type. Cluster IA corresponds to the samples that contain $\beta$-caryophyllene as the major constituent (47.48-60.58\%) and cluster IB corresponds to the samples in which caryophyllene oxide (19.91-29.15\%) and trans- $\alpha$-bergamotene $(20.93 \%)$ are the major constituents, both groups of samples being collected from trees growing in sandy soils. Cluster IIA corresponds to the samples in which caryophyllene oxide was the major constituent, and cluster IIB corresponds to the samples in which $\beta$-caryophyllene was the major constituent, both groups of samples being collected from trees growing in clay soils.

Although not all the constituents have been identified, no relationships were identified between absence/presence and/or increase/decrease of contents of the major constituents or any of the other constituents, and collection season. Given that the proportion of samples with $\beta$-caryophyllene and its oxide as the major constituent in both collection periods was the same. The random clustering of these samples, regardless of the collection period, also enabled the lack of seasonality on the chemical composition of oilresins of this species to be determined. However, the variation in chemical composition may be indirectly influenced by the availability of water since during the rainy season, by the activities of microorganisms, such as fungi and bacteria, which are favored by the increase in moisture, and by herbivorous insects, which are also intensified during this period, and would cause the plant to produce constituents that defend it against external agents.

As for $\mathrm{DBH}$, there is a tendency for trees with higher DBH to be chronologically older. ${ }^{35}$ Generally, young trees (smaller DBH) present higher physiological activities than older trees (larger DBH), a fact that may explain the continuity of oil production over time. Although the constituents of oilresin of copaiba are products resulting from the secondary metabolism of these plants, they derive from carbohydrates produced by the primary metabolism. ${ }^{45}$

Another fact to be considered is that the trees present a larger $\mathrm{DBH}(\geq 40 \mathrm{~cm})$ as they are in the reproductive phase, which may contribute to the lower continuity of production of this oilresin, as its physiological efforts are concentrated on the production of flowers, fruits and seeds. Likewise, these trees may be no longer producing compounds that defend the plant against external organisms, as its efforts are concentrated on producing the compounds necessary for the production of seeds, flowers and fruits in order to perpetuate this species.

Plowden ${ }^{35}$ suggests that the production of copaiba oil increases with DBH up to a maximum point, and trees with diameters between 55 and $65 \mathrm{~cm}$ present higher average production than trees with larger, or smaller diameters. However, the author does not find any relationship between $\mathrm{DBH}$ and the matrices and chemical composition of the oils of $C$. multijuga. A similar result was found for the species of $C$. paupera Dwyer and $C$. reticulata Ducke. ${ }^{24}$ In the present work, DBH also showed no significant influence on the chemical composition of this species. 


\section{Conclusion}

The chemical composition of the oilresin of C. multijuga Hayne was determined by GC-FID and GC-MS, and the results were evaluated by chemometric techniques of hierarchical cluster analysis and principal components analysis. Thirty-five constituents were identified: thirty-one sesquiterpenes and four diterpenes. The results obtained in the chromatographic analysis, analyzed by the HCA and PCA methods, reflect a pattern in the composition of the copaiba oils, $\beta$-caryophyllene and its oxide being major constituents of these samples. No quantitative variations were observed between the main constituents and the variables analyzed. However, the qualitative variations present a relationship only with the soil type in which the trees that supplied the samples were located. Other factors analyzed, like seasonality and $\mathrm{DBH}$, did not show a significant influence in the chemical composition of this species.

\section{Acknowledgments}

The authors thank Coordenação de Aperfeiçoamento de Pessoal de Nível Superior (CAPES), Conselho Nacional de Desenvolvimento Científico e Tecnológico (CNPq) and Fundação de Amparo à Pesquisa do Estado do Amazonas (FAPEAM).

\section{References}

1. Pio Corrêa, M.; Dicionário das Plantas Úteis do Brasil; Ministério da Agricultura: Rio de Janeiro, Brasil, 1931, p. 370.

2. Dwyer, J. D.; Brittonia 1951, 7, 143.

3. Martins-da-Silva, R. C. V.; Pereira, J. F.; Lima; H. C.; Rodriguésia 2008, 59, 455.

4. Veiga-Junior, V. F.; Patitucci, M. L.; Pinto, A. C.; Quim. Nova 1997, 20, 612 .

5. Monti, H.; Tiliacos, N.; Faure, R.; Phytochemistry 1996, 42, 1653.

6. Veiga-Junior, V. F.; Pinto, A. C.; Quim. Nova 2002, 25, 273.

7. Pieri, F. A.; Mussi, M. C.; Moreira, M. A. S.; Rev. Bras. Plantas Med. 2009, 11, 465.

8. Leandro, L. M.; Vargas, F. S.; Barbosa, P. C. S.; Neves, J. K. O.; Da Silva, J. A.; Veiga-Junior, V. F.; Molecules 2012, 17, 3866.

9. Governador do Estado do Amazonas, Decreto Estadual do Amazonas No. 25.044 de 1o. de junho de 2005, Proíbe o Licenciamento do Corte, Transporte e Comercialização de Madeira das Espécies de Andirobeiras e Copaibeiras e dá outras Providências, 2005. Available in: http://www.ipaam. br/legislacao/ESTADUAL/dec.\%20est.\%20n.\%C2\%BA\%20 $25.044, \% 20 \mathrm{de} \% 2001.06 .05 \% 20 \% 28$ pro $\%$ C $3 \%$ ADbe $\% 20$ o\%20licenciamento $\% 20 \mathrm{do} \% 20$ corte, $\% 20$ transporte $\% 20 \mathrm{e} \% 20$ comercializa $\% \mathrm{C} 3 \% \mathrm{~A} 7 \% \mathrm{C} 3 \% \mathrm{~A} 3 \mathrm{o} \% 20 \mathrm{de} \% 20$ madeira $\% 20$ das $\% 20$ esp $\%$ C3\% A9cies\%20de\%20andirobeiras $\% 20$ e $\% 20$ copaibeiras $\% 20$ e $\% 20$ d $\%$ C $3 \%$ A $1 \% 20$ outras $\% 20$ provid\%C3\%AAncias\%29.doc accessed on September 30, 2012.

10. Paiva, L. A. F.; Cunha, K. M. A.; Santos, F. A.; Gramosa, N. V.; Silveira, E. R.; Rao, V. S. N.; Phytother. Res. 2002, 16, 737.

11. Veiga-Junior, V. F.; Rosas, E. C.; Carvalho, M. V.; Henriques, M. G. M. O.; Pinto, A. C.; J. Ethnopharmacol. 2007, 112, 248.

12. Carvalho, J. C. T.; Cascon, V.; Possebon, L. S.; Morimoto, M. S. S.; Cardoso, L. G. V.; Kaplan, M. A. C.; Gilbert, B.; Phytother. Res. 2005, 19, 946.

13. Nogueira-Neto, J.; Lindoso, M. J. S.; Coelho, L. F.; Carvalho, R. A. F.; Rodrigues, T. G. P. M.; Araújo, A. G. P.; Girão, M. J. B. C.; Schor, E.; Acta Cir. Bras. 2011, 26, 20.

14. Gomes, N. M.; Rezende, C. M.; Fontes, S. P.; Matheus, M. E.; Pinto, A. C. ; Fernandes, P. D.; J. Ethnopharmacol. 2010, 128, 177.

15. Veiga-Junior, V. F.; Zunino, L.; Patitucci, M. L.; Pinto, A. C.; Calixto, J. B.; J. Pharm. Pharmacol. 2006, 58, 1405.

16. Brito, M. V. H.; Moreira, R. J.; Tavares, M. L. C.; Carballo, M. C. S.; Carneiro, T. X.; Santos, A. A. S.; Acta Cir. Bras. 2005, 20, 243.

17. Baylac, S.; Racine, P.; Int. J. Aromather. 2003, 13, 138.

18. Basile, A. C.; Sertie, J. A. A.; Freitas, P. C. D.; Zanini, A. C.; J. Ethnopharmacol. 1988, 22, 101.

19. Veiga-Junior, V. F.; Zunino, L.; Calixto, J. B.; Patitucci, M. L.; Pinto, A. C.; Phytother. Res. 2001, 15, 476.

20. Fernandes, R. M.; Pereira, N. A.; Paulo, L. G.; Rev. Bras. Farm. 1992, 73, 53.

21. Izumi, E.; Ueda-Nakamura, T.; Veiga-Junior, V. F.; Pinto, A. C.; Nakamura, C. V.; J. Med. Chem. 2012, 55, 2994.

22. Vasconcelos, A. F. F.; Godinho, O. E. S.; Quim. Nova 2002, 25, 1057.

23. Tappin, M. R. R.; Pereira, J. F. G.; Lima, L. A.; Siani, A. C.; Mazzei, J. L.; Ramos, M. F. S.; Quim. Nova 2004, 27, 240.

24. Rigamonte-Azevedo, O. C.; Wadt, P. G. S.; Wadt, L. H. O.; Veiga-Junior, V. F.; Pinto A. C.; Regiani, A. M.; Rev. Bras. Ol. Fibros. 2004, 8, 851

25. Biavatti, W. M.; Dossin, D.; Deschamps, F. C.; Lima, M. P.; Rev. Bras. Farm. 2006, 19, 230.

26. Cascon, V.; Gilbert, B.; Phytochemistry 2000, 55, 773.

27. Gramosa, N. V.; Silveira, E. R.; Cavalcanti, B. C.; Ferreira, J. R. O.; Almeida, F. S.; Rao, V. S.; Costa-Lotufo, L. V.; Odorico-de-Moraes, M.; Pessoa, C.; Rec. Prog. Med. Plants: 2010, 27, 235.

28. Wang, J.; Langenheim, J. H.; Younaah Zhiwu Yanjiu 1990, 12, 85.

29. Medeiros, R. S.; Vieira, G.; Forest Ecol. Manag. 2008, 256, 282. 
30. Macedo, C.A.; Langenheim, J. H.; Biochem. Syst. Ecol. 1989, 17, 207.

31. Macedo, C.A.; Langenheim, J. H.; Biochem. Syst. Ecol. 1989, 17,551 .

32. Zoghbi, M. G. B.; Lameira, O. A.; Oliveira, E. C. P.; J. Essent. Oil Res. 2007, 19, 504.

33. Lameira, O. A.; Martins-da-Silva, R. C. V.; Zoghbi, M. G. B.; Oliveira, E. C. P.; J. Essent. Oil Res. 2009, 21, 105.

34. Alencar, J. C.; Acta Amazônica 1982, 12, 75.

35. Plowden, C.; Econ. Bot. 2003, 57, 491.

36. Newton, P.; Watkinson, A. R.; Peres, C. A.; Forest Ecol. Manag. 2011, 261, 255.

37. Nascimento, J. C.; Langenheim, J. H.; Biochem. Syst. Ecol. 1986, $14,615$.

38. Herrero-Jáuregui, C.; Casado, M. A.; Zoghbi, M. G. B.; Martins-da-Silva, R. C.; Chem. Biodivers. 2011, 8, 674.

39. Langenheim, J. H.; Convis, C. L.; Macedo, C. A.; Stubblebine, W. H.; Biochem. Syst. Ecol. 1986, 9, 27.

40. Langenheim, J. H.; Am. Sci. 1990, 78, 16.

41. Arrhenius, S. P.; Langenheim, J. H.; Biochem. Syst. Ecol. 1983, 11,361 .

42. Langenheim, J. H.; Arrhenius, S. P.; Nascimento, J. C.; Biochem. Syst. Ecol. 1981, 9, 27.

43. Litvak, M. E.; Monson, R. K.; Oecologia 1998, 114, 531. 44. Phillips, M. A.; Croteau, R. B.; Trends Plant Sci. 1999, 4, 184. 45. Langenheim, J. H.; Plants Resins: Chemistry, Evolution, Ecology and Ethnobotany; Timber Press: Portland, Cambridge, 2003.

46. Adams, R. P.; Identification of Essential Oil Components by Gas Chromatography/Mass Spectrometry, $4^{\text {th }}$ ed.; Allured Publishing: Illinois, USA, 2007; National Institute of Standards and Technology (NIST); PC version of the NIST/EPA/NIH Mass Spectral Database; U. S. Department of Commerce: Gaithersburg, MD, USA, 1998.

47. Ward, J. H.; J. Am. Stat. Assoc. 1963, 58, 238; Benzécri, J. P.; L'Analyse des Données: la Taxinomie, Tome 1; Dunod: Paris, France, 1980.

48. Mardia, K. V.; Kent, J. T.; Bibby, J. M.; Multivariate Analysis; Academic Press: London, 1980.

49. Moita-Neto, J. M.; Moita, G. C.; Quim. Nova 1998, 21, 467.

50. Paiva, L. A. F.; Gurgel, L. A.; De Sousa, E. T.; Silveira, E. R.; Silva, R. M.; Santos, F. A.; Rao, V. S. N.; J. Ethnopharmacol. 2004, 93, 51.

51. Lima, S. R. M.; Veiga-Junior, V. F.; Christo, H. B.; Pinto, A. C.; Fernandes, P. D.; Phytother. Res. 2003, 17, 1048.

52. Sant'Anna, B. M. P.; Fontes, S. P.; Pinto, A. C.; Rezende, C. M.; J. Braz. Chem. Soc. 2007, 18, 984.

53. Gramosa, N. V.; Silveira, E. R.; J. Essent. Oil Res. 2005, 17, 130.

54. Oliveira, E. C. P.; Lameira, O. A.; Zoghbi, M. G. B.; Rev. Bras. Plantas Med. 2006, 8, 14.
55. Zoghbi, M. G. B.; Oliveira, E. C. P.; Martins-da-Silva, R. C. V.; Trigo, J. R.; J. Essent. Oil Res. 2009, 21, 501.

56. Sachetti, C. G.; Carvalho, R. R.; Paumgartten, F. J. R.; Lameira, O. A.; Caldas, E. D.; Food Chem. Toxicol. 2011, 49, 1080.

57. Zoghbi, M. G. B.; Martins-da-Silva, R. C. V.; Trigo, J. R.; J. Essent. Oil Res. 2009, 21, 403.

58. Veiga-Junior, V. F.; Pinto, A. C.; de Lima, H. C.; J. Essent. Oil Res. 2006, 18, 430.

59. Sköld, M.; Karlberg, A.; Matura, M.; Börje, A.; Food Chem. Toxicol. 2006, 44, 538.

60. Gouinguene, S. P., Turlings, T. C. J.; Plant Physiol. 2002, 129, 1296.

61. Omolo, M. O.; Okinyo, D.; Ndiege, I. O.; Lwande, W. L.; Hassanali.; Phytochemistry 2004, 65, 2797.

62. Rodilla, J. M.; Tinoco, M. T.; Morais, J. C.; Gimenez, C.; Cabrera, R.; Martín-Benito, D.; Castillo, L.; Gonzalez-Coloma, A.; Biochem. Syst. Ecol. 2008, 36, 167.

63. Cheng, S. S.; Wu, C. L.; Chang, H. T.; Kao, Y. T.; Chang, S. T.; J. Chem. Ecol. 2004, 30, 1957.

64. Goren, A. C.; Piozzi, F.; Akcicek, E.; Kılıç, T.; Çarıkçl, S.; Mozioglu, E.; Setzer, W. N.; Phytochem. Lett. 2011, 4, 448.

65. Ghelardini, C.; Galeotti, N.; Di Cesare Mannelli, L.; Mazzanti, G.; Bartolini, A.; II Farmaco 2001, 56, 387.

66. Zheng, G. Q.; Kenny, P.M.; Lam, L. K. T.; J. Nat. Prod. 1992, $55,999$.

67. Kubo, I.; Chaudhuri, S. K.; Kubo, Y.; Sanchez, Y.; Ogura, T.; Saito, T.; Ishikawa, H.; Haraguchi, H.; Planta Med. 1996, 62, 427.

68. Silva, S. L.; Figueiredo, P. M. S.; Yano, T.; Eur. J. Pharmacol. 2007, 576, 180.

69. Legault, J.; Pichette, A.; J. Pharm. Pharmacol. 2007, 59, 1643.

70. Di Sotto, A.; Mazzanti, G.; Carbone, F.; Hrelia, P.; Maffei, F.; Mutat. Res. 2010, 699, 23.

71. Amiel, E.; Ofir, R.; Dudai, N.; Soloway, E.; Rabinsky, T.; Rachmilevitch, S.; Evidence-Based Complementary and Alternative Medicine 2012, 2012, 1.

72. Tambe, Y.; Tsujiuchi, H.; Honda, G.; Ikeshiro, Y.; Tanaka, S.; Planta Med. 1996, 62, 469.

73. Tung, Y. T.; Chua, M. T.; Wang, S. Y.; Chang, S. T.; Bioresour. Technol. 2008, 99, 3908.

74. Chavan, M. J.; Wakte, P. S.; Shinde, D. B.; Phytomedicine 2010, $17,149$.

75. Sabulal, B.; Dan, M.; John, A.; Kurup, R.; Pradeep, N. S.; Valsamma, R. K.; George, G.; Phytochemistry 2006, 67, 2469.

76. Bülow, N.; König, W. A.; Phytochemistry 2000, 55, 141.

77. Zoghbi, M. G. B.; Oliveira, E. C. P.; Lameira, O.A.; J. Essent. Oil Res. 2007, 19, 504.

78. Carvalho, J. C. T.; Cascon, V.; Possebon, L. S.; Morimoto, M. S. S.; Cardoso, L. G. V.; Kaplan, M. A. C.; Gilbert, B.; Phytother. Res. 2005, 19, 946. 
79. Tincusi, B. M.; Jiménez, I. A.; Bazzocchi, I. L.; Moujir, L. M.; Mamani, Z. A.; Barroso, J. P.; Ravelo, A. G.; Hernández, B. V.; Planta Med. 2002, 68, 808.

80. Souza, A. B.; Martins, C. H. G.; Souza, M. G. M.; Furtado, N. A. J. C.; Heleno, V. C. G.; Sousa, J. P. B.; Rocha, E. M. P.; Bastos, J. K.; Cunha, W. R.; Veneziani, R. C. S.; Ambrósio, S. R.; Phytother. Res. 2011, 25, 215.
81. Souza, A. B.; Souza, M. G. M.; Moreira, M. A.; Moreira, M. R.; Furtado, N. A. J. C.; Martins, C. H. G.; Bastos, J. K.; Santos, R. A.; Heleno, V. C. G.; Ambrósio, S. R.; Molecules 2011, 16, 9611.

82. Janzen, D. H.; Biotropica 1974, 6, 69.

Submitted: March 6, 2012

Published online: October 5, 2012 